\title{
Potential for deep sea invasion by Mediterranean shallow water echinoids: pressure and temperature as stage-specific dispersal barriers
}

\author{
Craig M. Young ${ }^{1, *}$, Paul A. Tyler ${ }^{2}$, Lucienne Fenaux ${ }^{3, * *}$ \\ 'Department of Larval Ecology, Harbor Branch Oceanographic Institution, 5600 U.S. Hwy. 1 N, Ft. Pierce, Florida 34946, USA \\ ${ }^{2}$ Department of Oceanography, University of Southampton, Southampton Oceanography Centre, European Way, \\ Southampton SO14 3ZH, United Kingdom \\ ${ }^{3}$ Station Zoologique URA CNRS 716, Université Paris 6, INSU, La Darse, F-06230 Villefranche-sur-Mer, France
}

\begin{abstract}
Hypotheses about the origin of the deep sea fauna often assume that the deep sea was first colonized by cold water animals migrating through isothermal water columns in polar seas. Deep water in the Mediterranean Sea has much warmer temperatures than comparable depths in the larger ocean basins. Moreover, the entire water column may be virtually isothermal during the winter months, making oceanographic conditions in the Mediterranean analogous to those prevailing throughout most of the world ocean during the Mesozoic and Cenozoic. We investigated the physiological potential for deep sea invasion through a warm water column by studying the pressure and temperature tolerances of embryos and larvae of 3 species of shallow water Mediterranean echinoids, Paracentrotus lividus, Arbacia lixula, and Sphaerechinus granularis. Early life history stages of all 3 species tolerated pressures (to $150 \mathrm{~atm}$ ) much higher than those experienced in the adult environment. Cold temperatures $\left(<10^{\circ} \mathrm{C}\right)$ exacerbated the adverse effects of pressure; larvae were more likely to survive at deep sea pressures and warm temperatures than at shallow water pressures and cold temperatures. Tolerances to high pressures and low temperatures increased with ontogeny and varied with species. In the Mediterranean, high pressures should be a more important limiting factor than low temperatures. Nevertheless, some species have physiological tolerances that should allow them to colonize bathyal depths. Absence of these shallow water species from such depths must be attributed to factors other than pressure and temperature.
\end{abstract}

KEY WORDS: Mediterranean Echinoids Pressure B Barophysiology

\section{INTRODUCTION}

Long-standing debates about the origin of the deep sea fauna (e.g Moseley 1880, Madsen 1961, Menzies et al. 1973, Hessler \& Thistle 1975) have often focused on temperature as a factor that limits faunal exchange between depths. Most workers have assumed that species are narrowly adapted to the temperature range at which the adults presently occur, an idea that has been regarded as the most basic tenet of paleoecology (Menzies et al. 1973). If we accept this assumption, opportunities for deep sea colonization by shallow

\footnotetext{
-E-mail:youngc@hboi.edu

- Deceased
}

water animals should be limited to regions where temperature differences between shallow and deep waters are small. Thus, one common hypothesis is that deep sea habitats are invaded predominantly by coldadapted species at high latitudes (Kussakin 1973, Menzies et al. 1973, Hessler \& Thistle 1975, Hessler \& Wilson 1983). However, it is also possible that species entered the deep sea at lower latitudes during the Mesozoic and early Cenozoic (Menzies et al. 1973, Benson 1975, Hessler \& Wilson 1983), when the deep sea was much warmer than now (Berger 1979, Schopf 1980). The assumption that conservative thermal tolerances limit vertical distribution is integral to all of these arguments. It is surprising, therefore, that data on thermal tolerances of recruitment stages have not 
been used to either bolster or refute any of the existing hypotheses on deep sea faunal origins.

Temperature is not the only barrier that should prevent invasion of the deep sea by shallow water species; Hessler \& Wilson (1983) have identified substratum type. pressure, light, and nutrient availability as other probable limiting factors. Physiological adaptation to high pressure has been recently reviewed by Somero (1992) and Somero et al. (1983). In most parts of ocean, pressure and temperature covary, making it both difficult and irrelevant to isolate pressure as a limiting factor. It is ecologically important to study pressure as an isolated factor (i.e. holding temperature constant) only in isothermal and near-isothermal water columns such as the Norwegian Sea and the Mediterranean Sea. In the Mediterranean, the sill at Gibraltar prevents incursion of the cold, dense water (Antarctic Bottom Water and North Atlantic Deep Water) that keeps the abyssal temperature throughout most of the world ocean below $4^{\circ} \mathrm{C}$. Bottom temperature at 2000 to $3000 \mathrm{~m}$ is between 12 and $14^{\circ} \mathrm{C}$, which at some times of the year is only a few degrees cooler than the surface temperature (Sverdrup et al. 1942). For this reason, temperature is not expected to limit deep sea invasions in the Mediterranean; indeed, profiles of temperature and pressure in the Recent are probably similar to those prevailing throughout Mesozoic and early Cenozoic seas.

Echinoids with planktotrophic development are found from the intertidal zone to upper abyssal depths. No single species is known to occupy this entire range, though some eurybathic slope species have depth ranges that span many hundreds of meters (Gage \& Tyler 1991, Young 1992). Larval echinoids and postlarval ophiuroids of some bathyal species form pseudopopulations (Mileikovsky 1961) by settling outside the adult range where they are capable of growth, and, although initiating gametogenesis, rarely reach sexual maturity (Gage \& Tyler 1981a, b, Tyler pers. obs.). Thus, the realized niche of some echinoderm species may change in breadth as a function of stage, and surprisingly, the range of conditions tolerated by the larvae and juveniles, which are often considered to be the 'delicate' life history stages, are apparently broader than those of the aduits.

We have recently shown that the upper bathymetric limit of adult Echinus affinis, a lower bathyal echinoid species, corresponds closely with the pressure tolerances of its embryos (Young \& Tyler 1993). However, the embryos of numerous shallow water and bathyal species in Hawail, the North Atlantic, and the Bahamas can tolerate pressures far in excess of those encountered in the normal adult range (Young et al. 1996b, Tyler \& Young unpubl.). All of these experiments were done with newly fertilized zygotes at a single temperature. To date, there are no data on pres- sure tolerances of later larval stages, nor is information available on the responses of larvae to realistic combinations of pressure and temperature that might be encountered during the dispersal phase.

In this paper we explore the effects of temperature/pressure interaction on various early life history stages of 3 shallow water Mectiterranean echinoids. Our objective was to answer 3 closely related questions: (1) Is it possible for the larvae of shallow water animals from warm water to successfully colonize the deep sea? (2) Do pressure and/or temperature tolerances set the lower bathymetric limits of shallow water species? and (3) Are larvae which sink or are carried into deep water necessarily lost, or do they have the possibility of returning to recruit in the normal adult zone? These questions focus on ecological aspects of animal distribution in the sea, unlike earlier physiological work which documented the disruption of normal processes at the cellular and subcellular level under high pressures (reviewed by Marsland 1970 , McDonald 1975, Somero 1992). Carney et al. (1983), in a comprehensive review of benthic zonation, have predicted that further advances in out undersianding wiii come not from documentation of additional patterns, but from experimental work examining the physiological and ecological mechanisms underlying the observed patterns

Physiological tolerances of embryos and larvae are not the only factors that could limit invasion of the deep sea. Vertical distribution could potentially be controlled in any life history stage and by any biological or physical factor that limits dispersal or causes mortality. Nevertheless, we focus here on those planktonic dispersal stages that have the greatest potential for invasion of new habitats.

\section{MATERIALS AND METHODS}

The study was conducted in February 1994 at the Station Zoologique, Villefranche-sur-Mer on the Mediterranean coast of France. Individuals of Paracentrotus lividus, Arbacia lixula and Sphaerechinus granularis were collected by divers from shallow subtidal habitats near the marine lab and were maintained in running seawater until used. Spawning was induced by intracoelomic injection of $2 \mathrm{ml}$ of $0.55 \mathrm{M} \mathrm{KCl}$ and gametes were collected in finger bowls. Eggs from several females were mixed and inseminated with a dilute sperm suspension from several males, then checked for fertilization membranes before setting up the experiments. Each experiment included representation from all 3 species, so all 3 species were spawned and fertilized simultaneously. Fertilization rates approached $100 \%$ in every case. 
Aliquots of a dilute egg suspension from each species were pipetted into $8 \mathrm{ml}$ plastic scintillation vials which were completely filled with seawater and randomly assigned to 1 of 12 pressure/temperature combinations $\left(5,10,15^{\circ} \mathrm{C} \times 1,50,150\right.$ and $\left.250 \mathrm{~atm}\right)$. [Note: The SI unit for pressure is the Pascal (Pa) with $10^{5} \mathrm{~Pa}$ being equivalent to 1 atmosphere. We have elected to use atmospheres (atm) as 1 atm represents $10 \mathrm{~m}$ increase in water depth and makes pressure more easily understood as an ecological variable.] Each set included 3 vials, 1 containing zygotes from each species. The vials were immediately inserted into small pressure vessels (described by Young et al. 1996b) and pressurized within 15 min of fertilization, using a hand-operated Enerpac pump. Pressure vessels were incubated in water baths inside walk-in coldrooms at 5 and $15^{\circ} \mathrm{C}$ and in a Lauda refrigerated water bath at $10^{\circ} \mathrm{C}$. The pressure vessels were opened and the embryos were examined at 6, 12 and $24 \mathrm{~h}$ after fertilization. All pressure vessels of a given temperature were depressurized simultaneously, and the embryos were maintained in a depressurized state for no more than $30 \mathrm{~min}$. Samples were examined and photographed with an Olympus BH-2 compound microscope. At 6 and 12 h, 50 or more embryos from each sample were categorized by embryonic stage (e.g. cell number, blastula) and apparent regularity and synchrony of cleavage. At $24 \mathrm{~h}$, hatching had often occurred, making representative subsampling more difficult, so the stages and conditions of larvae were described qualitatively.

Swimming blastulae, gastrulae, prism and 4-arm larvae cultured at $20^{\circ} \mathrm{C}$ and 1 atm were transferred to the various pressure/temperature combinations described above to determine if development could proceed further and if survival was possible. These treatments were incubated for $20 \mathrm{~h}$ except in a few cases when they were incubated with the embryo treatments and terminated after $24 \mathrm{~h}$. At the end of each experiment, the larvae were placed in a bowl and examined with a dissecting microscope to determine what stage they had attained. Table 1 gives the definitions of larval stages, as used in this study. We also estimated visually the percentage of larvae that were swimming actively

\section{RESUITS}

\section{General observations}

All 3 sea urchin species, Paracentrotus lividus Arbacia lixula and Sphaerechinus granularis, live in shallow subtidal habitats $(0$ to $50 \mathrm{~m})$ as adults (Mortensen 1927), and spawn during the winter
Table 1. Paracentrotus lividus, Arbacia lixula and Sphaerechinus granularis. Classification of developmental stages, as used in survival studies of swimming larvae (Tables 2 to 4)

\begin{tabular}{|c|c|}
\hline Larval stage & Definition \\
\hline Blastula & $\begin{array}{l}\text { Hollow swimming larva, sometimes with } \\
\text { flattened vegetal plate but with no ap- } \\
\text { parent mesenchyme cells in the blasto- } \\
\text { coel }\end{array}$ \\
\hline Mesenchyme & $\begin{array}{l}\text { Blastula with mesenchyme migrating in } \\
\text { at the vegetal pole, but prior to the onset } \\
\text { of invagination }\end{array}$ \\
\hline Early gastrula & $\begin{array}{l}\text { Swimming larva with archenteron ex- } \\
\text { tending less than half way into the } \\
\text { blastocoel }\end{array}$ \\
\hline Gastrula & $\begin{array}{l}\text { Archenteron extends at least half way } \\
\text { into the blastocoel. Triradiate spicules } \\
\text { forming. Enterocoelous outpocketings } \\
\text { and/or stomodeal invagination may be } \\
\text { present. Incomplete gut }\end{array}$ \\
\hline Early prism & $\begin{array}{l}\text { Pyramidal larva with complete gut and } \\
\text { developing skeleton, but no arm rudi- } \\
\text { ments }\end{array}$ \\
\hline Late prism & $\begin{array}{l}\text { Prism stage with short postoral arm } \\
\text { rudiments }\end{array}$ \\
\hline Early 4-arm & $\begin{array}{l}\text { Short postoral and anterolateral arms } \\
\text { present, but comprising less than one- } \\
\text { third of total body length }\end{array}$ \\
\hline 4-arm & $\begin{array}{l}\text { Postoral and anterolateral arms comprise } \\
\text { more than one-third of total body length }\end{array}$ \\
\hline
\end{tabular}

months, in the Mediterranean, when the water temperature ranges from 12 to $15^{\circ} \mathrm{C}$. Early embryos are therefore unlikely to encounter either very warm or very cold temperatures during the early cleavage stages, nor are they likely to encounter pressures higher than a few atm at the time of spawning. In the Mediterranean, the range of temperatures they might encounter increases only slightly as a function of age because of a nearly isothermal water column. However, all 3 species live in the Atlantic ( $P$. Lividus and $S$ granularis as far north as Ireland, $A$. lixula off Morocco and in the Azores; Mortensen 1927), where the late stage larvae could easily sink or be transported into $2^{\circ} \mathrm{C}$ water

Developmental rate increased as a function of temperature in all 3 species (see Figs. 1, 3 \& 5). For example, during the first 6 h after fertilization, Paracentrotus lividus embryos reared at atmospheric pressure (1 atm) attained the 8 -cell stage at $5^{\circ} \mathrm{C}$, the 16 -cell stage at $10^{\circ} \mathrm{C}$, and the 32 -cell stage at $15^{\circ} \mathrm{C}$ (see Fig. 1). By $12 \mathrm{~h}$, the embryos at $5^{\circ} \mathrm{C}$ had undergone only 1 additional cleavage (see Figs. 1, 2A \& 4A), whereas those at both higher temperatures had hatched as swimming blastulae (see Figs. 1, 2E, I \& 4E, I). Thus, developmental rate at $5^{\circ} \mathrm{C}$ is not linear, but slows down with increasing age. 


\section{Pressure/temperature effects on early embryos}

\section{Paracentrotus lividus}

Embryos of Paracentrotus lividus were able to develop at pressures as high as 150 atm at 10 and $15^{\circ} \mathrm{C}$ (Fig. 1) and at least some embryos cleaved in all combinations of pressure and temperature with the exception of the $250 \mathrm{~atm} / 5^{\circ} \mathrm{C}$ treatment (Fig. 2). However, all cleavages were irregular in the $250 \mathrm{~atm}$ treatments (Figs. $1 \& 2 \mathrm{D}, \mathrm{H}, \mathrm{L}$ ) and also at $150 \mathrm{~atm} / 5^{\circ} \mathrm{C}$ (Fig. 2C)

At $6 \mathrm{~h}$, embryos incubated at both 10 and $15^{\circ} \mathrm{C}$ developed slightly slower at $150 \mathrm{~atm}$ than at $1 \mathrm{~atm}$ (Fig. 1). However, the variances at these stages are high, so the pattern may not be significant; it could also be caused by a slight delay in counting of one of the replicates

Twelve hours after fertilization, embryos reared at 10 and $15^{\circ} \mathrm{C}$ and the 2 lowest pressures ( 1 and $50 \mathrm{~atm}$ ) were fully formed swimming blastulae with large blastocoels and an even monolayer of ciliated ectodermal cells (Figs. 1 \& 2E, F, I, J). At $5^{\circ} \mathrm{C} / 150$ atm, embryos had undergone several cleavages (Fig 2C), but the cleavages were abnormali it was common to see blastomeres of uneven sizes and unusual numbers of blastomeres resulting from asynchronous cleavages (e.g. 3 - and 6 -cell stages). At $5^{\circ} \mathrm{C} / 250 \mathrm{~atm}$, there were no normal cleavages whatsoever (Fig. 1), but the cytoplasm in zygotes became uneven in appearance and the egg membranes began to take on irregular textures and
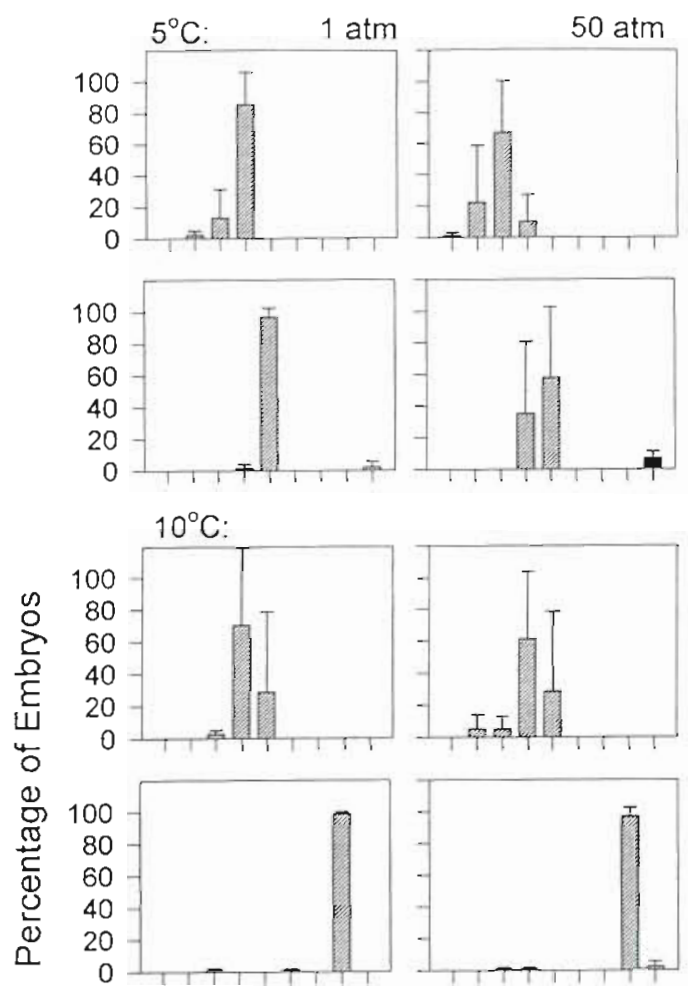

$15^{\circ} \mathrm{C}$
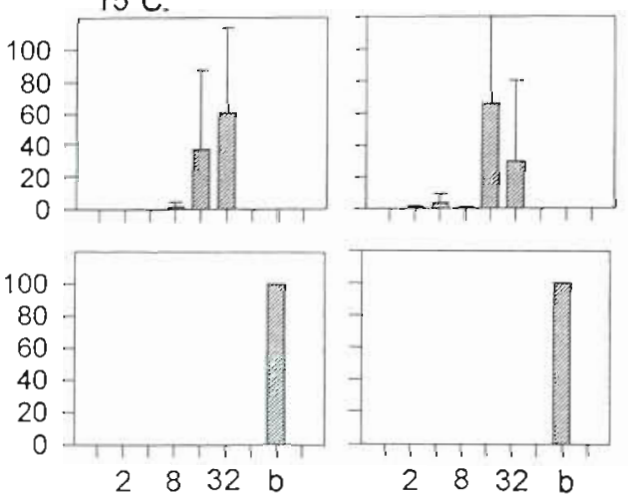

Develop
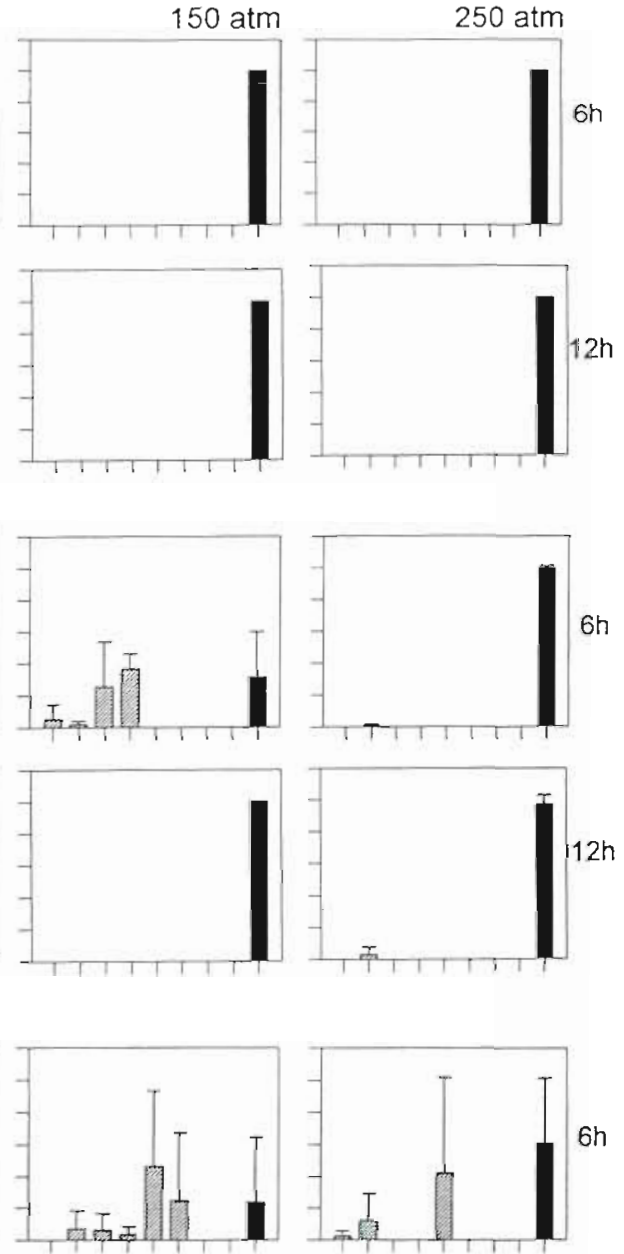

Fig. 1 Paracentrotus liv1dus. Percentage of embryos attaining various stages of development at different combinations of temperature $(5,10$ and $\left.15^{\circ} \mathrm{C}\right)$ and pressure $(1,50$, 150 and 250 atm) after 6 and 12 h incubation periods. Hatched bars represent living embryos. Black bars indicate the number of dead or abnormal embryos. Developmental stage: 2,2 -cell; 8, 8-cell; 32, 32-cell; b, blastula. Error bars are standard deviations 
shapes (Fig. 2D). At $10^{\circ} \mathrm{C} / 150$ atm, numerous cleavages occurred, but the embryos never attained the blastula stage and many of the cleavages appeared irregular (Figs. 1 \& 2G). At $10^{\circ} \mathrm{C} / 250$ atm, about half of the embryos proceeded to uneven 4 - or 8 -armed stages and the remainder of the zygotes became rough in appearance without undergoing any successful cleavages (Figs. $1 \& 2 \mathrm{H}$ ). At the highest temperature, $15^{\circ} \mathrm{C} / 150 \mathrm{~atm}$, some embryos developed abnormally and others became functional swimming blastulae (Figs, 1 \& $2 \mathrm{~K})$. Many cleavages occurred at $15^{\circ} \mathrm{C} / 250 \mathrm{~atm}$ as well, but all of these produced abnormal embryos having irregularly sized and shaped blastomeres which resulted in non-spherical embryos that never hatched (Fig. 2L).
Embryos of Paracentrotus lividus were examined qualitatively 20 or $24 \mathrm{~h}$ after fertilization. At this time, there were no major changes in the patterns of normal development that had been observed by $12 \mathrm{~h}$. At $15^{\circ} \mathrm{C} /$ 250 atm, no normal embryos were found. Embryos reared at $15^{\circ} \mathrm{C} / 1$ atm and $15^{\circ} \mathrm{C} / 50$ atm had flattened vegetal plates on the posterior end and were producing primary mesenchyme tissue at the vegetal end of the blastocoel. Pressure had a sublethal effect on developmental rate at $15^{\circ} \mathrm{C} / 150 \mathrm{~atm}$. Only about half of the blastulae at this pressure had hatched by $24 \mathrm{~h}$ and none had started producing primary mesenchyme cells.

At $10^{\circ} \mathrm{C}$, hatching occurred by $24 \mathrm{~h}$ at $1 \mathrm{~atm}$ and $50 \mathrm{~atm}$. At $10^{\circ} \mathrm{C} / 150 \mathrm{~atm}$, between 30 and $50 \%$ of the $5^{\circ} \mathrm{C}$

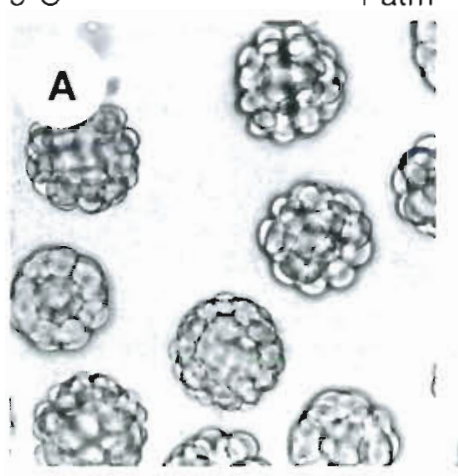

50 atm $150 \mathrm{~atm}$

$250 \mathrm{~atm}$

$10^{\circ} \mathrm{C}$

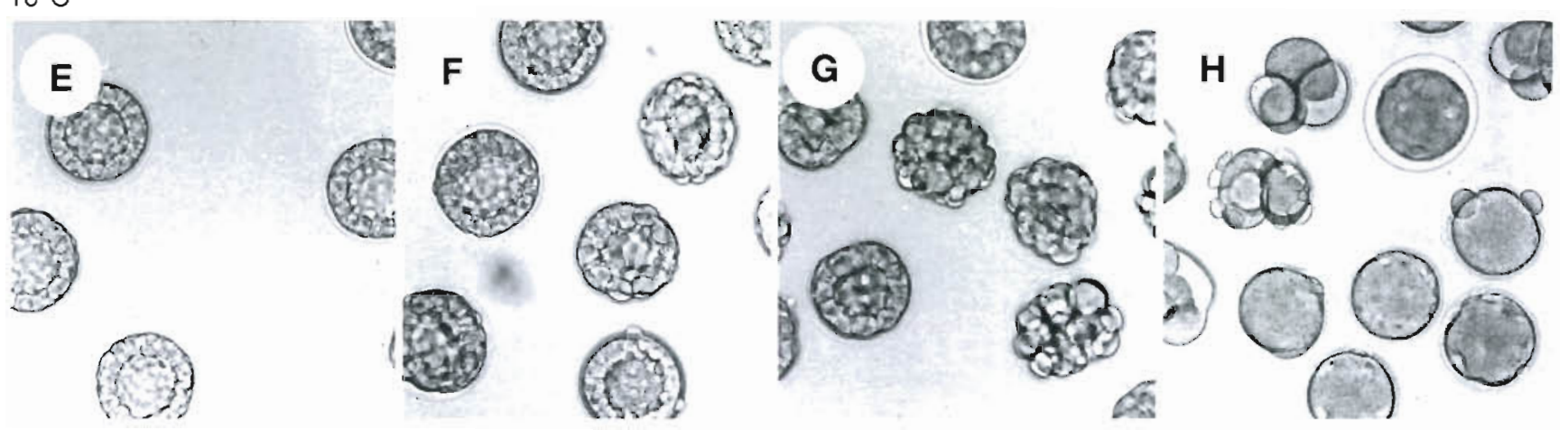

$16^{\circ} \mathrm{C}$
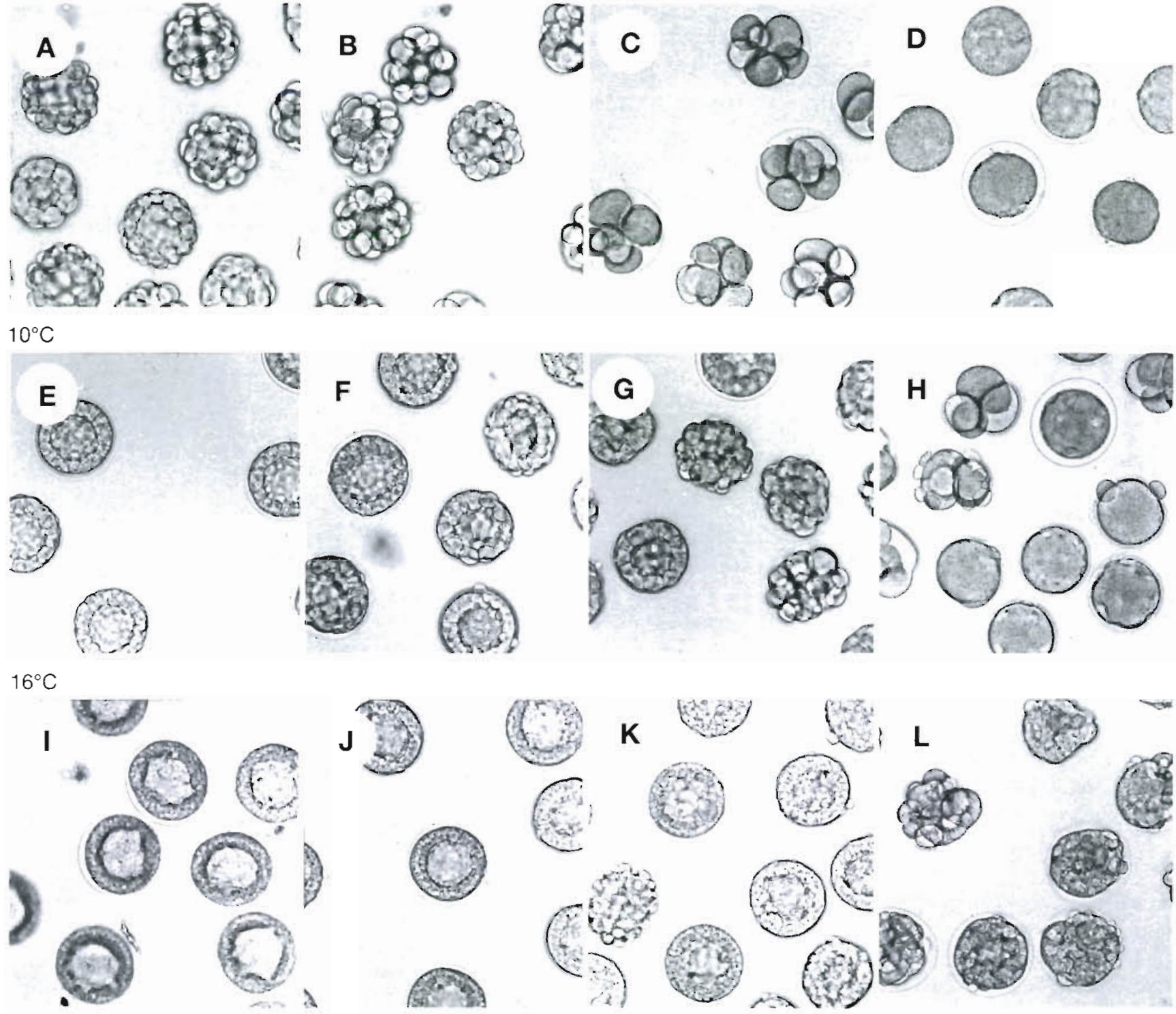

Fig. 2. Paracentrotus lividus. Embryos reared for $12 \mathrm{~h}$ under the various pressure/temperature combinations in Fig. 1 (A) $5^{\circ} \mathrm{C} / 1$ atm; (B) $5^{\circ} \mathrm{C} / 50 \mathrm{~atm}_{\text {; }}$ (C) $5^{\circ} \mathrm{C} / 150 \mathrm{~atm}$ ( D) $5^{\circ} \mathrm{C} / 250 \mathrm{~atm} ;$ (E) $10^{\circ} \mathrm{C} / 1 \mathrm{~atm} ;(\mathrm{F}) 10^{\circ} \mathrm{C} / 50 \mathrm{~atm} ;$ (G) $10^{\circ} \mathrm{C} / 150 \mathrm{~atm} ;$ (H) $10^{\circ} \mathrm{C} / 250 \mathrm{~atm}$; (I) $16^{\circ} \mathrm{C} / 1 \mathrm{~atm}$; (J) $16^{\circ} \mathrm{C} / 50 \mathrm{~atm} ;(\mathrm{K}) 16^{\circ} \mathrm{C} / 150 \mathrm{~atm} ;$ (L) $16^{\circ} \mathrm{C} / 250$ atm. Diameters of fertilization membranes (e.g. in D) are approximately $120 \mu \mathrm{m}$ 
embryos had developed to unhatched blastulae. A few (estimate: $<5 \%$ ) of the eggs had cleaved into normallooking 2 -cell embryos at $10^{\circ} \mathrm{C} / 250 \mathrm{~atm}$; the remainder were still uncleaved or had undergone very irregular cleavage

The embryos held at $5^{\circ} \mathrm{C}$ had not hatched by $24 \mathrm{~h}$ at any pressure, though normal-looking unhatched blastulae were present at 1 and $50 \mathrm{~atm}$. At $5^{\circ} \mathrm{C} / 150 \mathrm{~atm}$ we found 2 normal-looking 32-cell embryos and more than 100 embryos that had undergone abnormal cleavages. No normal embryos at all were present at $5^{\circ} \mathrm{C} /$ 250 atm, though about $10 \%$ had undergone an irregular first cleavage by $24 \mathrm{~h}$.

\section{Arbacia lixula}

Pressures of 150 and $200 \mathrm{~atm}$ inhibited development in Arbacia lixula at all temperatures (Figs. $3 \& 4$ ) in much the same way as in Paracentrotus lividus. However, A. lixula completed more normal cleavages at high temperatures than at low temperatures before development became irregular (Figs. 3 \& 4). Hatching occurred in a small percentage of embryos at $15^{\circ} \mathrm{C}$ / $150 \mathrm{~atm}$ (Fig $4 \mathrm{~K}$ ) and a few embryos continued to develop at this pressure even at $10^{\circ} \mathrm{C}$ (Fig. $4 \mathrm{G}$ ). By $24 \mathrm{~h}$, some of the latter had developed as far as the 32-cell stage.
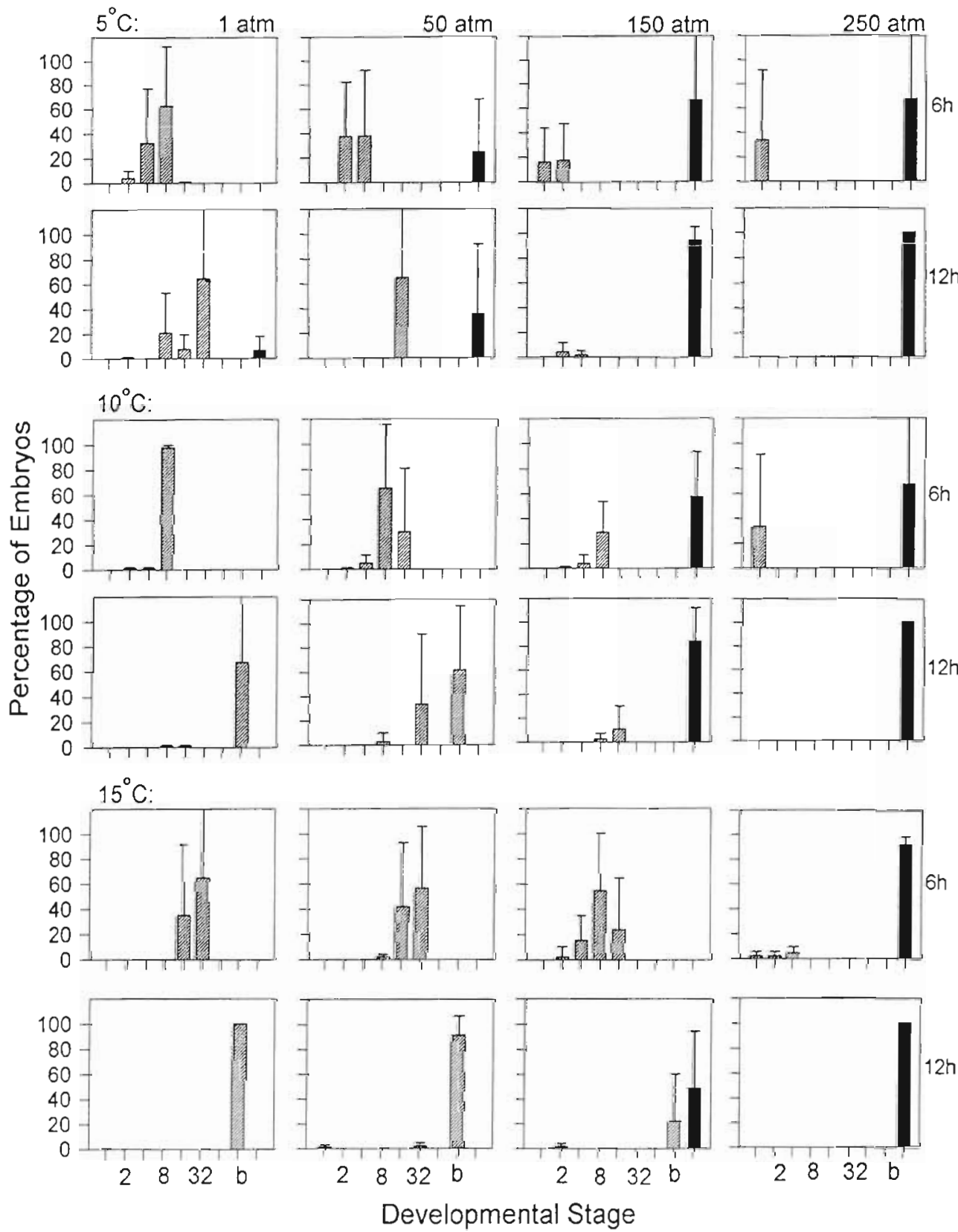

Fig. 3. Arbacia lixula. Percentage of embryos attaining various stages of development at different combinations of temperature $\left(5,10\right.$ and $\left.15^{\circ} \mathrm{C}\right)$ and pressure $(1,50,150$ and 250 atm) after 6 and $12 \mathrm{~h}$ incubation periods. Hatched bars represent living embryos. Black bars indicate the number of dead or abnormal embryos Developmental stage: 2 , 2-celli 8, 8-cell; 32, 32-celli b, blastula. Error bars are standard deviations 
Normal development of Arbacia lixula embryos occurred at $50 \mathrm{~atm}$ in all 3 temperature treatments (Figs. 3 \& $4 \mathrm{~B}, \mathrm{~F}, \mathrm{~J})$, but about $30 \%$ of the embryos at $5^{\circ} \mathrm{C} / 50 \mathrm{~atm}$ had become abnormal by 12 h (Fig. $3 \& 4$ B). Development rate was slightly slower at $50 \mathrm{~atm}$ than at $1 \mathrm{~atm}$ in the 5 and $10^{\circ} \mathrm{C}$ treatments, but not at $15^{\circ} \mathrm{C}$ (Fig. 3).

At $5^{\circ} \mathrm{C} / 150 \mathrm{~atm}$, embryos of Arbacia lixula cleaved at a slower rate than Paracentrotus lividus, but the ultimate effect was the same; all but a few embryos appeared abnormal in both species.

The first hatching occurred within $24 \mathrm{~h}$ after fertilization at $10^{\circ} \mathrm{C} / 1 \mathrm{~atm}, 15^{\circ} \mathrm{C} / 1 \mathrm{~atm}, 15^{\circ} \mathrm{C} / 50 \mathrm{~atm}$ and $15^{\circ} \mathrm{C} / 150 \mathrm{~atm}$. Unhatched blastulae were present at $5^{\circ} \mathrm{C} / 1$ atm and at $10^{\circ} \mathrm{C} / 50 \mathrm{~atm}$. There were clear morphological differences among pressure treatments in hatched blastulae that had been reared at $15^{\circ} \mathrm{C}$. Blastulae at 1 atm had already developed a flattened and thickened vegetal plate and ingression of primary mesenchyme cells into the blastocoel had begun. At 50 and 150 atm, by contrast, blastulae remained circular; neither vegetal thickening nor primary mesenchyme was apparent. The few normal appearing embryos that were present at $12 \mathrm{~h}$ in the $5^{\circ} \mathrm{C} / 150 \mathrm{~atm}$ treatment became abnormal by $24 \mathrm{~h}$, but the few normal ones at $10^{\circ} \mathrm{C} / 150 \mathrm{~atm}$ were still normal looking and had attained the 32 -cell stage by $24 \mathrm{~h}$.

$5^{\circ} \mathrm{C}$

$1 \mathrm{~atm} \quad 50 \mathrm{~atm}$ $150 \mathrm{~atm}$ $250 \mathrm{~atm}$

A

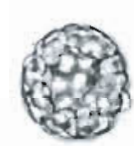

है)
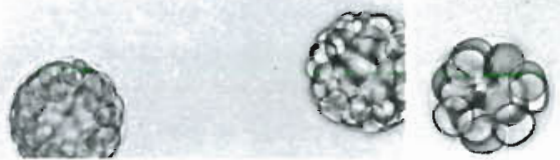

B
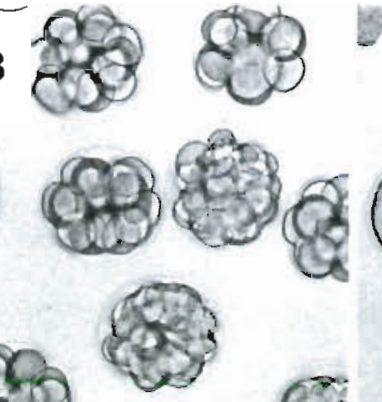

C
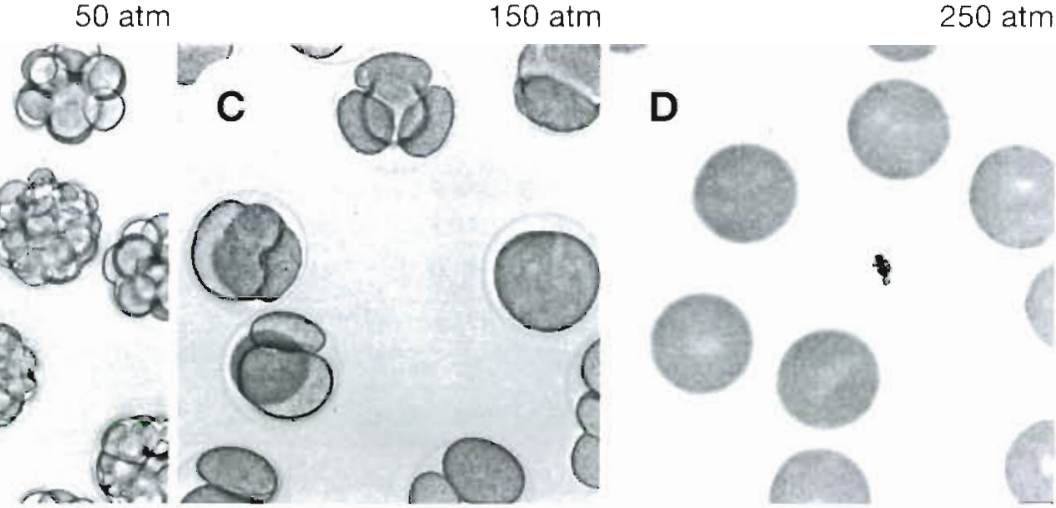

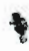

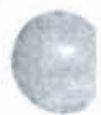

$10^{\circ} \mathrm{C}$
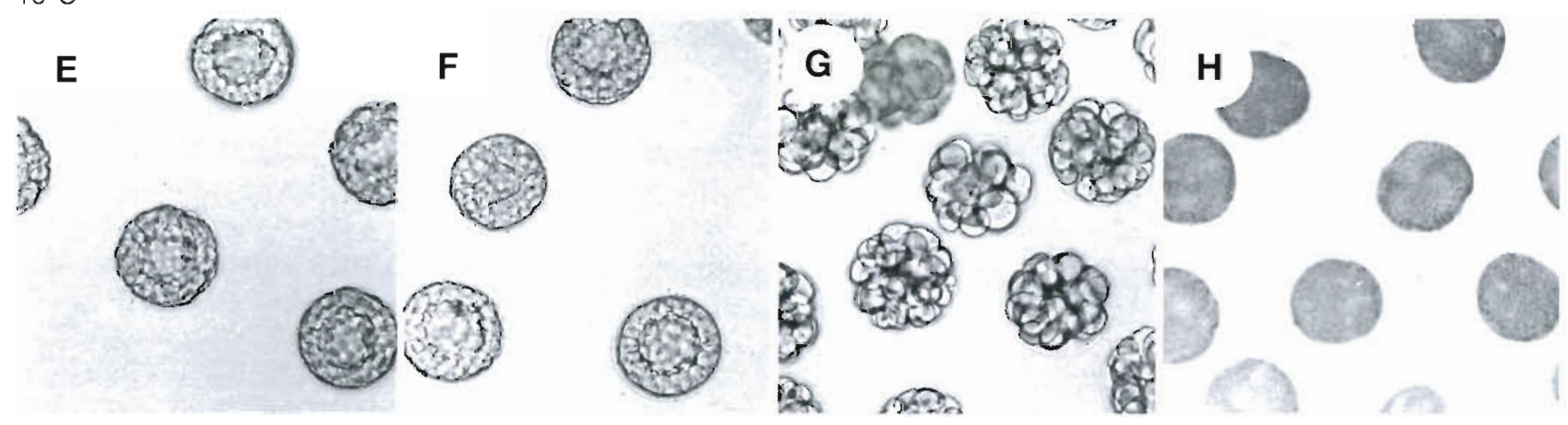

$16^{\circ} \mathrm{C}$

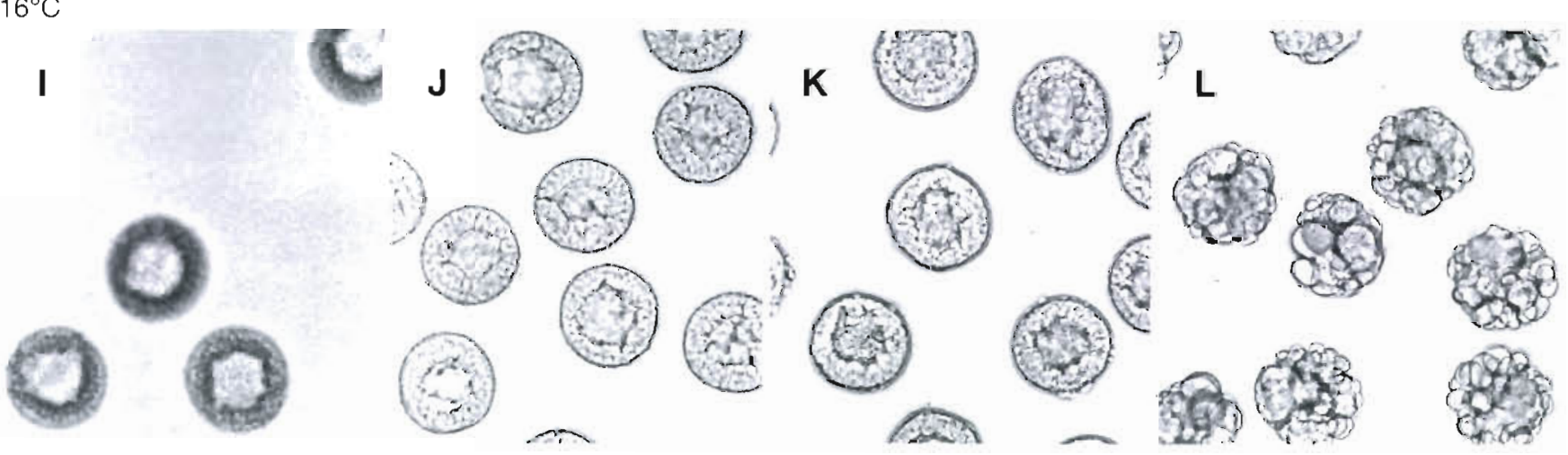

Fig. 4. Arbacia lixula. Embryos reared for $12 \mathrm{~h}$ under the various pressure/temperature combinations in Fig. 3 . (A) $5^{\circ} \mathrm{C} / 1$ atm; (B) $5^{\circ} \mathrm{C} / 50 \mathrm{~atm}$; (C) $5^{\circ} \mathrm{C} / 150 \mathrm{~atm} ;$ (D) $5^{\circ} \mathrm{C} / 250 \mathrm{~atm}$; (E) $10^{\circ} \mathrm{C} / 1 \mathrm{~atm} ;(\mathrm{F}) 10^{\circ} \mathrm{C} / 50 \mathrm{~atm}$; (G) $10^{\circ} \mathrm{C} / 150 \mathrm{~atm} ;(\mathrm{H}) 10^{\circ} \mathrm{C} / 250 \mathrm{~atm} ;(\mathrm{I}) 16^{\circ} \mathrm{C} / 1 \mathrm{~atm}$; (J) $16^{\circ} \mathrm{C} / 50 \mathrm{~atm} ;(\mathrm{K}) 16^{\circ} \mathrm{C} / 150 \mathrm{~atm} ;(\mathrm{L}) 16^{\circ} \mathrm{C} / 250 \mathrm{~atm}$. Diameters of fertilization membranes are approximately $120 \mu \mathrm{m}$ 


\section{Sphaerechinus granularis}

Sphaerechinus granularis embryos were less tolerant of high pressures than either of the other species investigated. No normal development occurred at 250 or $150 \mathrm{~atm}$ except in the $15^{\circ} \mathrm{C} / 150 \mathrm{~atm}$ treatment (Figs. 5 \& 6C, D, G, H, L), where a few blastulae hatched by $24 \mathrm{~h}$. However, these hatched blastulae did not swim and appeared much less healthy than actively swimming blastulae incubated at lower pressures.

No normal development occurred in the $5^{\circ} \mathrm{C} / 50$ atm treatment (Figs. $5 \& 6 \mathrm{~B}$ ) and abnormalities were present at $10^{\circ} \mathrm{C} / 50 \mathrm{~atm}$ (Figs. $5 \& 6 \mathrm{~F}$ ). Both of the other species developed normally at these combinations of pressure and temperature. Sphaerechinus granularis is intolerant of $5^{\circ} \mathrm{C}$ even at 1 atm pressure, as indicated by about $20 \%$ abnormality after $12 \mathrm{~h}$ (Figs. $5 \& 6 \mathrm{~A}$ ). At the end of the $24 \mathrm{~h}$ experiment, however, there were still some normal looking 16 - and 32-cell embryos present in this treatment.

\section{Stage-specific survival and development of larvae}

Paracentrotus lividus blastulae, prisms, and 4-arm plutei survived all temperatures down to $5^{\circ} \mathrm{C}$ and all pressures up to $150 \mathrm{~atm}$ (Table 2). Developmental rates of blastulae were affected by pressure within each temperature and by temperature within each pressure. The $5^{\circ} \mathrm{C} / 250$ atm treatment was lethal for all 3 stages, but a pressure of 250 atm was generally
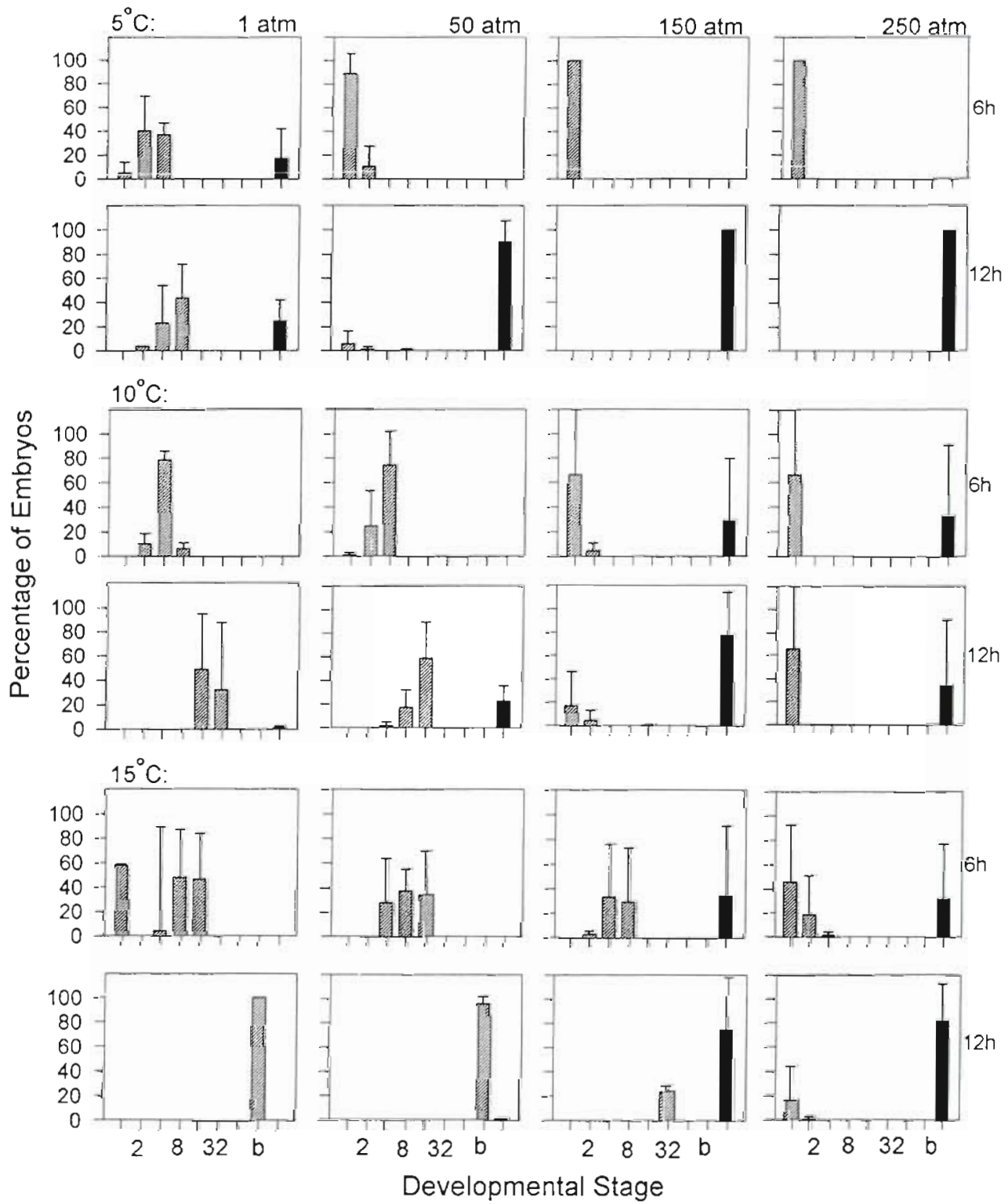

Fig. 5. Sphaerechinus granularis. Percentage of embryos attaining various stages of development at different combinations of temperature (5. 10 and $15^{\circ} \mathrm{C}$ ) and pressure $(1,50,150$ and $250 \mathrm{~atm})$ after 6 and $12 \mathrm{~h}$ incubation periods. Hatched bars represent living embryos. Black bars indicate the number of dead or abnormal embryos. Developmental stage: 2, 2-cell; 8. 8-cell; 32, 32-cell; b, blastula. Error bars are standard deviations 
tolerated at 10 and $15^{\circ} \mathrm{C}$. A possible exception was in the 4 -arm stage, where some abnormalities were observed but larvae were still swimming. These data suggest that larvae of this species could invade lower bathyal depths in the Mediterranean, but not outside the Straits of Gibraltar.

Developmental rates of Arbacia lixula larvae in 3 of the 4 stages tested (Table 3 ) demonstrated the same temperature and pressure effects observed in Paracentrotus lividus. We observed mortality only in the gastrula stage at $5^{\circ} \mathrm{C} / 250 \mathrm{~atm}$. Minor abnormalities occurred during the transition from blastula to gastrula in this same treatment, and also at $5^{\circ} \mathrm{C} / 250$ atm and at $10^{\circ} \mathrm{C} / 150 \mathrm{~atm}$ and $10^{\circ} \mathrm{C} / 250 \mathrm{~atm}$. Gastrulae in these latter treatments were swimming, but appeared smaller and denser than those cultured at higher temperatures or lower pressures. Early 4-arm plutei cultured at $5^{\circ} \mathrm{C} / 250 \mathrm{~atm}$ were still alive, but the tips of the arm rods were protruding through the tissue, indicating that the larvae were severely stressed and probably would not survive indefinitely.

Spherechinus granularis larvae demonstrated roughly the same patterns of larval survival as the other 2 species (Table 4). There was no survival at any stage in

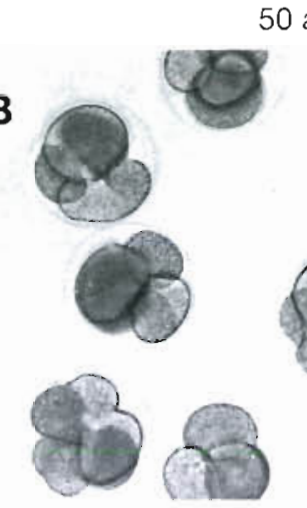

$50 \mathrm{~atm}$

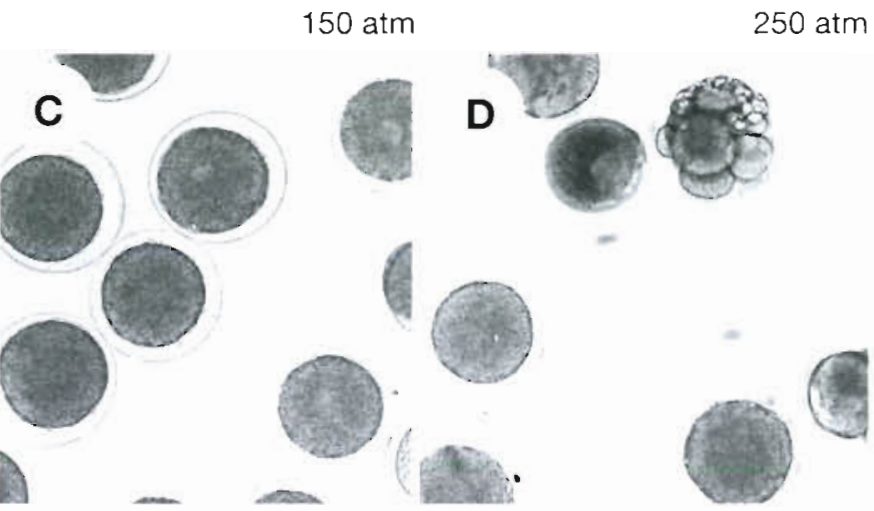

$10^{\circ} \mathrm{C}$
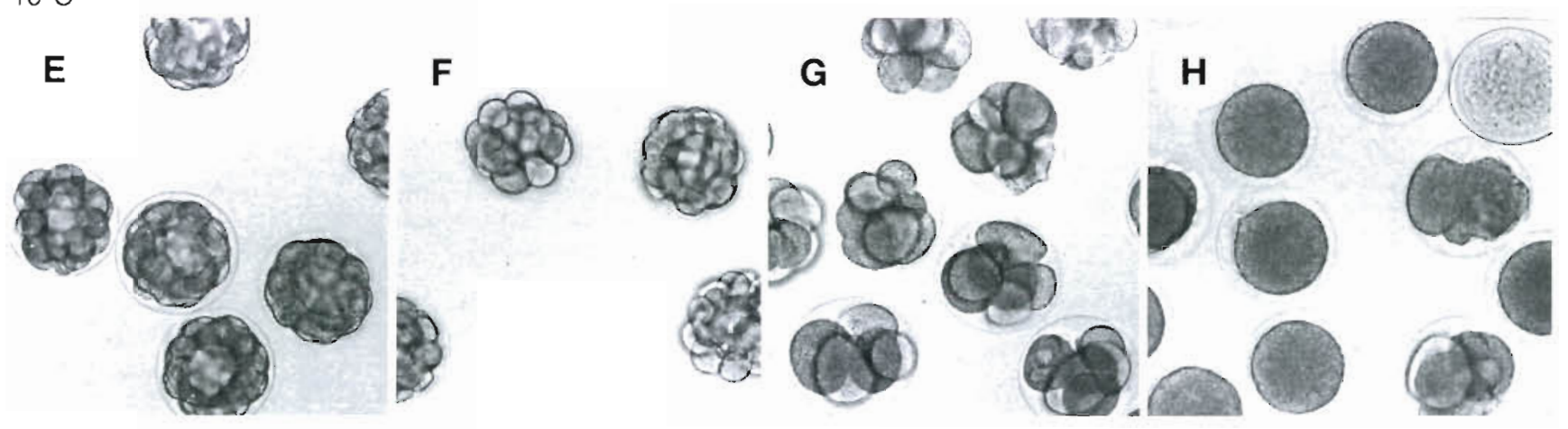

$16^{\circ} \mathrm{C}$
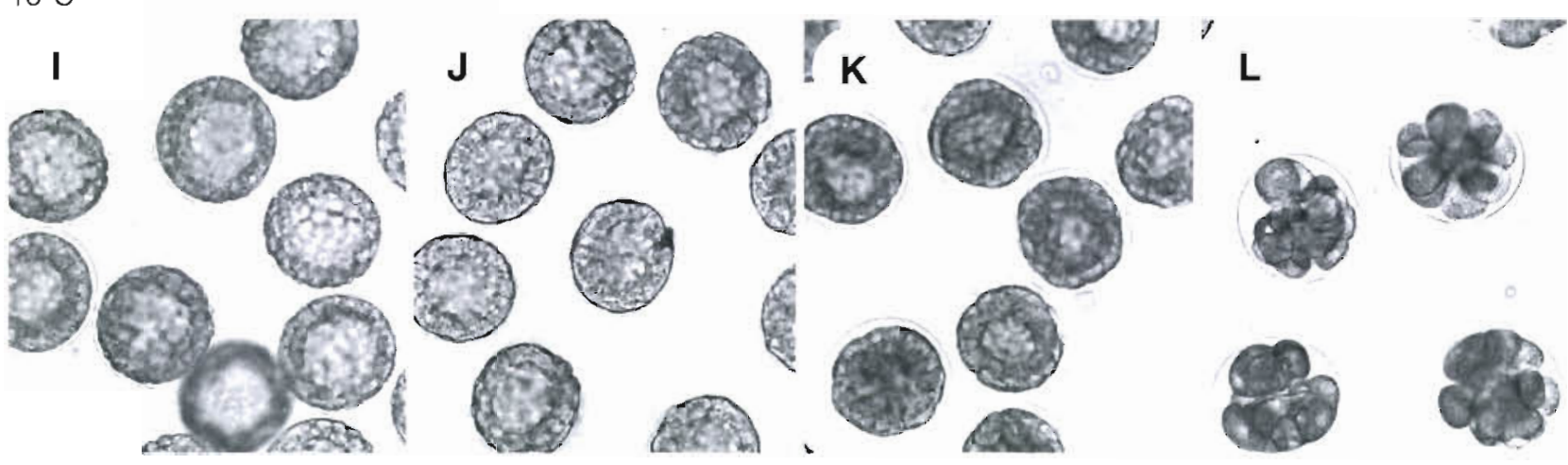

Fig. 6. Spahaerechinus granularis. Embryos reared for $12 \mathrm{~h}$ under the various pressure/temperature combinations $1 \mathrm{n}$ Fig. 5 . (A) $5^{\circ} \mathrm{C} / 1 \mathrm{~atm}$; (B) $5^{\circ} \mathrm{C} / 50 \mathrm{~atm}$ (C) $5^{\circ} \mathrm{C} / 150 \mathrm{~atm}$; (D) $5^{\circ} \mathrm{C} / 250 \mathrm{~atm} ;$ (E) $10^{\circ} \mathrm{C} / 1 \mathrm{~atm}$; (F) $10^{\circ} \mathrm{C} / 50 \mathrm{~atm} ;(\mathrm{G}) 10^{\circ} \mathrm{C} / 150 \mathrm{~atm} ;(\mathrm{H}) 10^{\circ} \mathrm{C} / 250 \mathrm{~atm}$; (I) $16^{\circ} \mathrm{C} / 1 \mathrm{~atm}$ (J) $16^{\circ} \mathrm{C} / 50 \mathrm{~atm}$; (K) $16^{\circ} \mathrm{C} / 150 \mathrm{~atm}$ (L) $16^{\circ} \mathrm{C} / 250 \mathrm{~atm}$. Diameters of fertilization membranes (e.g. in $\mathrm{C}$ ) are approxi- 


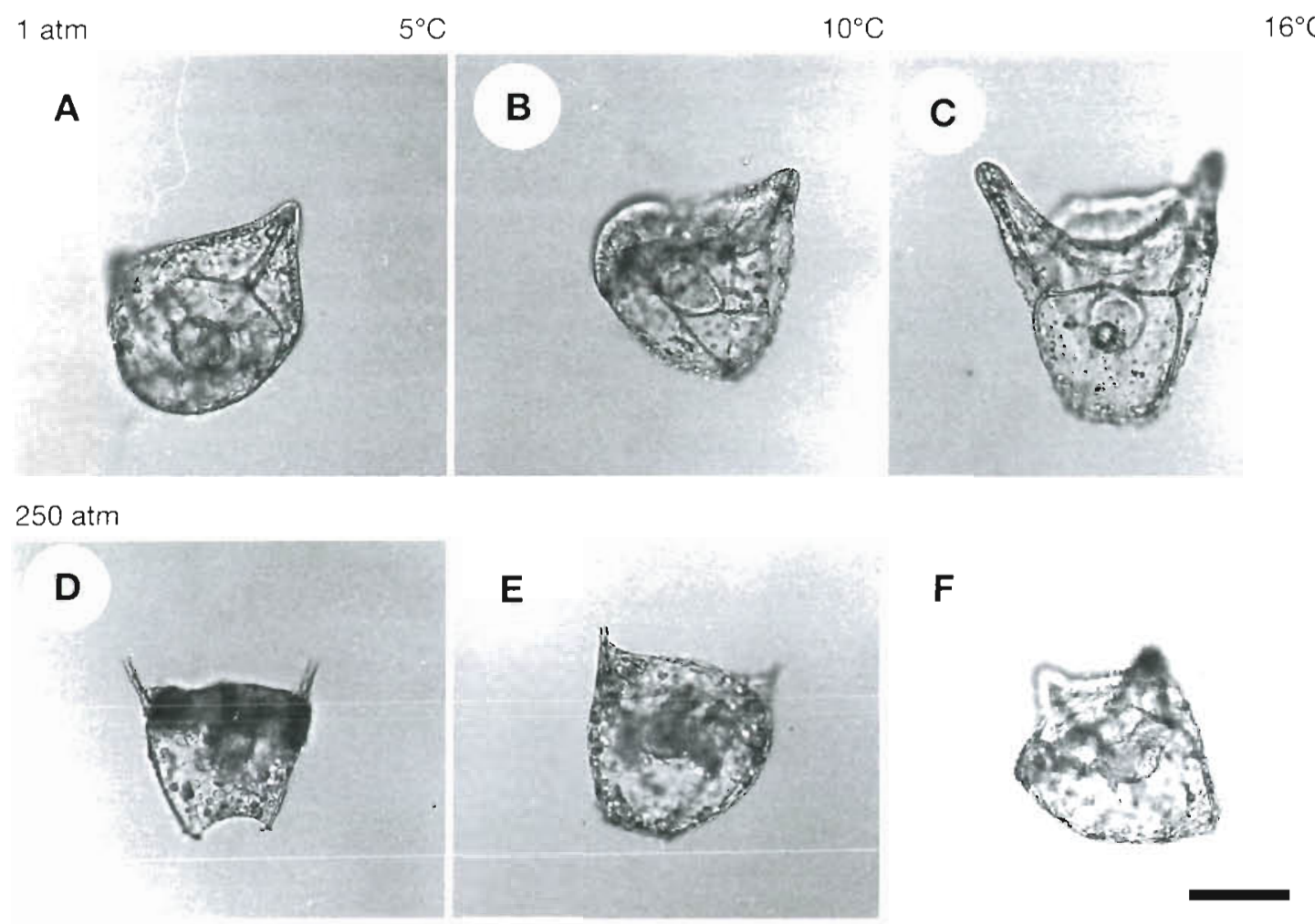

Fig. 7. Sphaerechinus granularis. Four-arm larvae reared for 20 or $24 \mathrm{~h}$ (see 'Materials and methods') at 1 atm at (A) $5^{\circ} \mathrm{C},(\mathrm{B}) 10^{\circ} \mathrm{C}$, and (C) $16^{\circ} \mathrm{C}$ and at $250 \mathrm{~atm}$ at (D) $5^{\circ} \mathrm{C},(\mathrm{E}) 10^{\circ} \mathrm{C}$ and (F) $16^{\circ} \mathrm{C}$. Scale bar $=150 \mu \mathrm{m}$

the $5^{\circ} \mathrm{C} / 250$ atm treatment. Gastrulae either died or regressed to the blastula stage at $5^{\circ} \mathrm{C} / 150$ atm. There were also deaths and abnormalities in the pluteus stage at $10^{\circ} \mathrm{C} / 250$ atm (Table 4 ). Fig 7 shows differences between echinopluteus larvae incubated at 1 and $250 \mathrm{~atm}$. At $15^{\circ} \mathrm{C}$, pluteus larvae appeared normal at 250 atm, but with shorter arms than in those reared at atmospheric pressure (Fig. 7C, F). Larvae incubated at $5^{\circ} \mathrm{C} / 250 \mathrm{~atm}$ and $10^{\circ} \mathrm{C} / 250 \mathrm{~atm}$ showed signs of tissue regression, as indicated by the tips of fenestrated arm rods extending beyond the body tissues (Fig. 7D, E).
Table 2. Paracentrotus lividus. Survival and development of swimming larvae reared initially at $20^{\circ} \mathrm{C} / 1 \mathrm{~atm}$ then transferred to various combinations of pressure and temperature for 20 to $24 \mathrm{~h}$ (see 'Matenals and methods'।. Qualitative survival data based on observations of all individuals $(n>50)$ in each culture are denoted with symbols as follows: + , living and swimming; 0 , dead; , living but abnormal. Definitions of larval stages are given in Table 1

\begin{tabular}{|c|c|c|c|c|}
\hline $\begin{array}{l}\text { Beginning } \\
\text { stage }\end{array}$ & $\begin{array}{l}\text { Pressure } \\
\text { (atm) }\end{array}$ & $5^{\circ} \mathrm{C}$ & $\begin{array}{l}\text { ng stage and surviv } \\
\qquad 10^{\circ} \mathrm{C}\end{array}$ & $15^{\circ} \mathrm{C}$ \\
\hline Blastula & $\begin{array}{r}1 \\
50 \\
150 \\
250\end{array}$ & $\begin{array}{l}\text { Gastrula }(+) \\
\text { Gastrula }(+) \\
\text { Mesenchyme }(+) \\
(0)\end{array}$ & $\begin{array}{l}\text { Early prism }(+) \\
\text { Gastrula }(+) \\
\text { Early gastrula (+) } \\
\text { Early gastrula (+) }\end{array}$ & $\begin{array}{l}\text { Early prism (+) } \\
\text { (no data) } \\
\text { Gastrula }(+) \\
\text { Early gastrula }(+)\end{array}$ \\
\hline Late prism & $\begin{array}{r}1 \\
50 \\
150 \\
250\end{array}$ & $\begin{array}{l}\text { Early } 4 \text {-arm }(+) \\
\text { Early } 4 \text {-arm }(+) \\
\text { Early } 4 \text {-arm }(+) \\
\text { Early } 4 \text {-arm }(0,-)\end{array}$ & $\begin{array}{l}\text { Early 4-arm (+) } \\
\text { Early } 4 \text {-arm }(+) \\
\text { Early } 4 \text {-arm }(+) \\
\text { Early } 4 \text {-arm }(+)\end{array}$ & $\begin{array}{l}\text { Early } 4 \text {-arm }(+) \\
\text { Early } 4 \text {-arm }(+) \\
\text { Early } 4 \text {-arm }(+) \\
\text { Early } 4 \text {-arm }(+)\end{array}$ \\
\hline 4-arm & $\begin{array}{r}1 \\
50 \\
150 \\
250\end{array}$ & $\begin{array}{l}4-\operatorname{arm}(+) \\
4-\operatorname{arm}(+) \\
4-\operatorname{arm}(+) \\
4-\operatorname{arm}(0,-)\end{array}$ & $\begin{array}{l}4-\operatorname{arm}(+) \\
4-\operatorname{arm}(+) \\
4-\operatorname{arm}(+) \\
4-\operatorname{arm}(+)\end{array}$ & $\begin{array}{l}4-\operatorname{arm}(+) \\
4-\operatorname{arm}(+) \\
4-\operatorname{arm}(+) \\
4-\operatorname{arm}(-)\end{array}$ \\
\hline
\end{tabular}

\section{DISCUSSION}

The Mediterranean Sea is one of very few places where it might be possible for the larva of a warm water invertebrate from the shallow sublittoral zone to reach lower bathyal depths without experiencing a large change in temperature. During the winter, which is the reproductive season of several shallow water echinoids in this region, mistral winds from the north cool the surface waters, thereby rendering the entire water column nearly isothermal. For this reason, the Mediterranean is a good model for the conditions that may have existed throughout most of the world oceans before the polar ice caps formed in the 
Table 3. Arbacia lixula. Survival and development of swimming larvae reared initially at $20^{\circ} \mathrm{C} / 1 \mathrm{~atm}$ then transferred to various combinations of pressure and temperature for 20 to $24 \mathrm{~h}$ (see 'Materials and methods'). See Table 2 for explanation of symbols and Table 1 for definitions of stages

\begin{tabular}{|c|c|c|c|c|}
\hline $\begin{array}{l}\text { Beginning } \\
\text { stage }\end{array}$ & $\begin{array}{l}\text { Pressure } \\
\text { (atm) }\end{array}$ & $5^{\circ} \mathrm{C}$ & $\begin{array}{l}\text { ng stage and survival } \\
\qquad 10^{\circ} \mathrm{C}\end{array}$ & $15^{\circ} \mathrm{C}$ \\
\hline Blastula & $\begin{array}{r}1 \\
50 \\
150 \\
250\end{array}$ & $\begin{array}{l}\text { Early prism (+) } \\
\text { Gastrula (+) } \\
\text { Gastrula (+) } \\
\text { Gastrula (-) }\end{array}$ & $\begin{array}{l}\text { Early prism (+) } \\
\text { Early prism (+) } \\
\text { Gastrula (-) } \\
\text { Gastrula (-) }\end{array}$ & $\begin{array}{l}\text { Early prism }(+) \\
\text { Early prism }(+) \\
\text { Early prism }(+) \\
\text { Gastrula }(+)\end{array}$ \\
\hline Gastrula & $\begin{array}{r}1 \\
50 \\
150 \\
250\end{array}$ & $\begin{array}{l}\text { Early prism }(+) \\
\text { Early prism }(+) \\
\text { Early prism }(+) \\
\text { Gastrula }(0,-,+)\end{array}$ & $\begin{array}{l}\text { Early prism (+) } \\
\text { Early prism (+) } \\
\text { Early prism (+) } \\
\text { Gastrula (+) }\end{array}$ & $\begin{array}{l}\text { Early } 4 \text {-arm }(+) \\
\text { Early } 4 \text {-arm }(+) \\
\text { late prism }(+) \\
\text { Gastrula }(+)\end{array}$ \\
\hline Early prism & $\begin{array}{c}1 \\
50 \\
150 \\
250\end{array}$ & $\begin{array}{l}\text { Early } 4 \text {-arm (+) } \\
\text { Late prism }(+) \\
\text { Early prism (+) } \\
\text { Early prism (+) }\end{array}$ & $\begin{array}{l}\text { Early } 4 \text {-arm (+) } \\
\text { Late prism (+) } \\
\text { Late prism (+) } \\
\text { Early prism (+) }\end{array}$ & $\begin{array}{l}\text { Early } 4 \text {-arm }(+) \\
\text { Early } 4 \text {-arm }(+) \\
\text { Early } 4-\operatorname{arm}(+) \\
\text { Early prism }(+)\end{array}$ \\
\hline Early 4-arm & $\begin{array}{c}1 \\
50 \\
150 \\
250\end{array}$ & $\begin{array}{l}4-\operatorname{arm}(+) \\
4-\operatorname{arm}(+) \\
4-\operatorname{arm}(+) \\
\text { Early } 4-\operatorname{arm}(-)\end{array}$ & $\begin{array}{l}4-\operatorname{arm}(+) \\
4-\operatorname{arm}(+) \\
4-\operatorname{arm}(+) \\
\text { Early } 4 \text {-arm }(+)\end{array}$ & $\begin{array}{l}4-\operatorname{arm}(+) \\
4-\operatorname{arm}(+) \\
4-\operatorname{arm}(+) \\
\text { Early } 4-\operatorname{arm}(+)\end{array}$ \\
\hline
\end{tabular}

ula developed all the way to the swimming blastula stage at $16^{\circ} \mathrm{C} / 150 \mathrm{~atm}$. Pressure tolerances increased with larval age; the 4-arm echinoplutei of these 2 species survived at 250 atm, which is equivalent to an upper abyssal depth of $2500 \mathrm{~m}$. Thus, the swimming larval stages that would be the most likely invaders of the deep sea are also the most tolerant of deep sea conditions.

If larvae can tolerate pressures more than one order of magnitude higher than where the adults occur, why are these echinoids not found in deeper water? Perhaps settlement occurs at depth but survival is low. Juveniles of the deep sea ophiuroids Ophiura ljungmani and Ophiocten gracilis sometimes settle outside the adult depth range but do not survive there (Gage \& Tyler 1981a, b). Post-settle-

Cenozoic. The 'Challenger' scientists initially suspected that the deep sea was mostly colonized in the Paleozoic (Moseley 1880), but more recently a number of workers (Zenkevitch \& Birstein 1956, Zenkevitch 1959, Madsen 1961) have suggested that the Mesozoic and early Cenozoic were periods of major deep sea invasion. Our experiments with animals living under similar thermal conditions are therefore relevant to the broad question of deep sea colonization.

Embryos of only 2 species of echinoderms living at depths greater than $1500 \mathrm{~m}$ have been cultured in the laboratory (Young \& Tyler 1993, Young et al. 1996a). Both were obligately barophilic, and the upper limit of distribution corresponded roughly with the embryonic pressure tolerance in both species. However, work with upper bathyal and littoral species from tropical and temperate seas (Marsland 1938, 1950, Young et al. 1996b) shows that most echinoderms can withstand pressures much greater than those found near the lower limits of their vertical ranges. In the Mediterranean echinoids we studied, high pressure affects both cleavage success and developmental rate, but the thresholds for these effects are much higher than one would predict on the basis of bathymetric distribution. Only the highest pressure tested, 250 atm, inhibited early development at all temperatures and in all species. Both Paracentrotus lividus and Arbacia lix- ment mortality outside the normal depth range of Paracentrotus lividus, Arbacia lixula and Sphaerechinus granularis has not yet been studied. It would be interesting to transplant juveniles and adults to deep water to determine whether they survive and to investigate physical and biological sources of mortality.

M. L. Pedrotti (pers. comm.) has collected living larvae of Paracentrotus lividus and Arbacia lixula from $400 \mathrm{~m}$ in the Ligurian Sea, where they had apparently been advected downward at an oceanic front. It is not known whether such larvae ultimately perish in the bathypelagic zone, whether they settle at bathyal depths and die as juveniles, or whether they are able to return to shallow water for settlement. A preliminary
Table 4. Sphaerechinus granularis. Survival and development of swimming larvae reared initially at $20^{\circ} \mathrm{C} / 1$ atm then transferred to various combinations of pressure and temperature for 20 to $24 \mathrm{~h}$ (see 'Materials and methods'). See

Table 2 for explanation of symbols and Table 1 for definitions of stages

\begin{tabular}{|c|c|c|c|c|}
\hline $\begin{array}{l}\text { Beginning } \\
\text { stage }\end{array}$ & $\begin{array}{l}\text { Pressure } \\
\text { (atm) }\end{array}$ & Endi & $\begin{array}{l}\text { ing stage and survi } \\
\qquad 10^{\circ} \mathrm{C}\end{array}$ & $15^{\circ} \mathrm{C}$ \\
\hline Blastula & $\begin{array}{r}1 \\
50 \\
150 \\
250\end{array}$ & $\begin{array}{l}\text { Mesenchyme (+) } \\
\text { Blastula }(+) \\
\text { Blastula (+) } \\
(0)\end{array}$ & $\begin{array}{l}\text { Mesenchyme (+) } \\
\text { Mesenchyme (+) } \\
\text { Mesenchyme (+) } \\
\text { Mesenchyme (+) }\end{array}$ & $\begin{array}{l}\text { Early gastrula (+) } \\
\text { Early gastrula (+) } \\
\text { Mesenchyme (+) } \\
\text { Mesenchyme (+) }\end{array}$ \\
\hline Gastrula & $\begin{array}{r}1 \\
50 \\
150 \\
250\end{array}$ & $\begin{array}{l}\text { Gastrula (+) } \\
\text { Gastrula (+) } \\
\text { Blastula (0.-) } \\
(0)\end{array}$ & $\begin{array}{l}\text { Early prism (+) } \\
\text { Gastrula (+) } \\
\text { Gastrula (+) } \\
\text { Gastrula (+) }\end{array}$ & $\begin{array}{l}\text { Late prism }(+) \\
\text { Late prism }(+) \\
\text { Early prism }(+) \\
\text { Gastrula }(+)\end{array}$ \\
\hline Early 4-arm & $\begin{array}{r}1 \\
50 \\
150 \\
250\end{array}$ & $\begin{array}{l}\text { Early 4-arm }(+) \\
\text { Early 4-arm }(+) \\
\text { Early 4-arm (+) } \\
\text { Early 4-arm (0) }\end{array}$ & $\begin{array}{l}\text { Early } 4 \text {-arm }(+) \\
\text { Early } 4-\operatorname{arm}(+) \\
\text { Early } 4-\operatorname{arm}(+) \\
\text { Early } 4-\operatorname{arm}\left(0_{-}\right)\end{array}$ & $\begin{array}{l}\text { Early } 4 \text {-arm }(+) \\
\text { Early } 4 \text {-arm }(+) \\
\text { Early } 4 \text {-arm }(+) \\
\text { Early } 4 \text {-arm }(+)\end{array}$ \\
\hline
\end{tabular}


analysis of the energetics of echinoid larvae suggests that migration from bathyal depths to the surface may be possible (Young et al. 1996c). Echinoid larvae generally have a low center of gravity (Pennington \& Strathmann 1990, Young 1995) which causes them to orient vertically and swim predominantly upward.

Our experiments on pressure/temperature effects in various larval stages demonstrate that temperature per se is probably not the major limiting factor on colonization of deep sea habitats, but that high pressures interact with low temperatures to set limits on invasion. However, the limits imposed by these physiological barriers should occur much deeper in the Mediterranean than the adult sea urchins are ever found. Based on our findings, we predict that echinoids should be no more capable of invading the deep sea in isothermal polar seas than in warmer waters, because pressure would limit larval survival at similar depths in both situations. The subtemperate species we studied, which occur on both sides of Gibraltar, would be much more likely to invade deep water in the Mediterranean than in the open Atlantic, as colder temperatures exacerbate the adverse effects of pressure during the early life history stages. We also have shown that invasion of the deep sea does not depend on occasional outliers with broader temperature and pressure tolerances than the majority of the population. Virtually all individual larvae of the species tested should be capable of surviving the physical conditions at bathyal depths. Future discussions about the origins of the deep sea fauna should focus on habitat suitability and food availability as well as temperature and pressure tolerances. Most importantly, one should not assume that a species is incapable of tolerating the physical conditions of the deep sea until tolerances have been tested empirically.

Acknowledgements. We (C.M.Y and P.A.T.) thank Drs Jacques Soyer and Paul Laval for the excellent welcome and facilities at the Station Zoologique, Villefranche-sur-Mer. Maria-Luisa Pedrotti provided insights on Mediterranean larvae during several discussions. This study was completed during the tenure of NATO grant CRG-900628, which is gratefully acknowledged. This is contribution number 1182 from Harbor Branch Oceanographic Institution. We dedicate this work to the memory of its late third author, Lucienne Fenaux, whose contributions to Larval Biology were important and numerous and whose kundness and grace will surely be missed by her many colleagues, students and friends.

\section{LITERATURE CITED}

Benson RH (1975) The origin of the psychrosphere as recorded in changes of deep-sea ostracode assemblages. Lethaia 8:69-83

Berger WH (1979) Impact of deep-sea drilling on paleoceanography. In: Talwani M, Hay W. Ryan WBF (eds) Deep drilling results in the Atlantic Ocean: continental margins and paleoenvironment. American Geophysical Union, Washington, DC, p 297-314

Carney RS, Haedrich RL, Rowe GT (1983) Zonation of fauna in the deep sea. In: Rowe GT (ed) The sea, Vol 8. WileyInterscience, New York, p 371-398

Gage JD, Tyler PA (1981a) Non-viable seasonal settlement of larvae of the upper bathyal brittlestar Ophiocten gracilis in the Rockall Trough abyssal. Mar Biol 64:153-161

Gage JD. Tyler PA (1981b) Reappraisal of the age composition, growth and survivorship of the deep-sea brittlestar Ophiura ljungmani from size structure in a time series from the Rockall Trough. Mar Biol 64:163-172

Gage JD, Tyler PA (1991) Deep-sea biology. A natural history of organisms at the deep-sea floor. Cambridge University Press, Cambridge

Hessler RR, Thistle D (1975) On the place of origin of deepsea isopods. Mar Biol 32:155-165

Hessler RR, Wilson GDF (1983) The origin and biogeography of malacostracan crustaceans in the deep sea. In: Sims RW, Price JH, Whalley PES (eds) Evolution in time and space: the emergence of the biosphere. Academic Press, New York, p $22 \overline{7}-254$

Kussakin OG (1973) Peculiarities of the geographical and vertical distribution of marine isopods and the problem of deep-sea fauna origin. Mar Biol 23:19-34

Madsen FJ (1961) On the zoogeography and origin of the abyssal faund in view of the knowledge of the Porcellanasteridae. Galathea Rep 4:177-218

Marsland DA (1938) The effects of high hydrostatic pressure upon cell division in Arbacia eggs. J Cell Comp Physiol $12: 57-70$

Marsland D (1950) The mechanism of cell division: temperature pressure experiments on the cleaving eggs of Arbacia punctulata. J Cell Comp Physiol 36:205-227

Marsland D (1970) Pressure-temperature studies on the mechanisms of cell division. In: Zimmerman AM (ed) High pressure effects on cellular processes. Academic Press, New York, p 259-311

McDonald AG (1975) Physiological aspects of deep-sea biology. Cambridge University Press, Cambridge

Menzies RH, George RY, Rowe GT (1973) Abyssal environment and ecology of the world oceans. Wiley, New York

Mileikovsky SA (1961) Character and nature of deep-water eurybathic forms of invertebrates with pelagic larvae taking as an example the polychaete Euphrosyne borealis Oersted 1843 from the North Atlantic. Okeanologiya 1 687-697

Mortensen T (1927) Handbook of the echinoderms of the British Isles. Oxford University Press, London

Moseley HN (1880) Deep-sea dredging and life in the deep sea. Nature 21:543-547,569-572,591-593

Pennington JT, Strathmann RR (1990) Consequences of the calcite skeletons of planktonic echinoderm larvae for orientation, swiming, and shape. Biol Bull (Woods Hole) 179:121-133

Schopf TJM (1980) Paleoceanography. University Press, Cambridge, MA

Somero GN (1992) Adaptations to high hydrostatic pressure. Annu Rev Physiol 54:557-577

Somero GN, Siebenaller JF, Hochachka PW (1983) Biochemical and physiological adaptations of deep sea animals. In: Rowe GT (ed) The sea, Vol 8. Wiley-Interscience, New York, p 261-330

Sverdrup HU, Johnson MW, Fleming RH (1942). The oceans, their physics, chemistry and general blology. PrenticeHall, NJ 
Young CM (1992) Episodic recruitment and cohort dominance in Bahamian echinold populations at bathyal depths. In: Columbo G, Ferrari I, Ceccherelli VU, Rossi R (eds) Marine eutrophication and population dynamics. Oisen \& Olsen, Fredensborg, p 239-246

Young CM (1995) Behavior and locomotion during the dispersal phase of larval life. In: McEdward LR (ed) Ecology of manne invertebrate larvae. CRC Press, Boca Raton, FL, p 249-277

Young CM, Devin MG, Jaeckle WB, Ekaratne SUK, George SB (1996c) The potential for ontogenetic vertical migration by larvae of bathyal echinoderms. Oceanol Acta 19:263-271

Young CM, Tyler PA (1993) Embryos of the deep sea echinoid Echinus affinis require high pressure for development. Limnol Oceanogr 38:178-181

This article was submitted to the editor
Young CM, Tyler PA, Emson RH (1996b) Embryonic pressure tolerences of bathyal and littoral echinoids from the tropical Atlantic and Pacific Oceans. In: Emson RH, Smith AB, Campbell AC (eds) Echınoderm research 1995. Balkema, Rotterdam, p 325-334

Young CM, Tyler PA, Gage JD (1996a) Vertical distribution correlates with embryonic pressure tolerances in the deep-sea asteroid Plutonaster bifrons. J Mar Biol Assoc UK 76:749--757

Zenkevitch LA (1959) Certain zoological problems concerned with the study of the abyssal and ultra-abyssal zones of the ocean. XVth Int Congr Zool, London, p 215-218

Zenkevitch LA, Birstein IA (1956) Studies of the deep water fauna and related problems. Deep Sea Res 4:54-64

Manuscript received: November 1, 1996 Revised version accepted: May 16, 1997 